\title{
IMPLEMENTASI INVERTER SEBAGAI PENGENDALI MOTOR INDUKSI TIGA FASA DENGAN METODE SPACE VECTOR PULSE WIDTH MODULATION (SVPWM)
}

\author{
Emmanuel Agung Nugroho \\ Program Studi Teknik Mekatronika \\ Politeknik Enjinering Indorama \\ Email: lekagung@yahoo.com
}

\begin{abstract}
ABSTRAK
Penelitian ini merancang dan menganalisa inverter 3 fasa sebagai pengendali motor induksi 3 fasa dengan metode Space Vector Pulse Width Modulation (SVPWM) menggunakan IC terprogram. Pengujian dilakukan untuk membuktikan bahwa inverter terkendali SVPWM memiliki efisiensi tegangan keluaran lebih baik jika dibandingkan dengan Variable Speed Drive (VSD) inverter yang dijual dipasaran. Data hasil pengujian yang dilakukan dengan menggunakan osiloskope, volt meter dan clamp arus membuktikan hasil perancangan inverter terkendali SVPWM memiliki efisiensi tegangan keluaran sebesar 83,3 \% pada frekuensi $50 \mathrm{~Hz}$. Hal ini lebih baik jika dibandingkan Variable Speed Drive dengan metode Volt/Hertz control yang menghasilkan efisiensi tegangan keluaran pada frekuensi $50 \mathrm{~Hz}$ sebesar 75,9\%. Pada pengujian motor induksi 3 fasa 2,2 KW membuktikan metode SVPWM Inverter mampu menekan arus mula sebesar 59,1\% dan menekan konsumsi arus nominal pada frekuensi $50 \mathrm{~Hz}$ sebesar $90,1 \%$.
\end{abstract}

Kata kunci: motor induksi, variable speed drive, inverter 3 fasa, space vector pulse width modulation $(S V P W M)$

\begin{abstract}
This study is design and analyze 3-phase inverter for driving 3 phase induction motor by using Space Vector Pulse Width Modulation (SVPWM) control method implemented in a programmable IC. Tests carried out to prove that inverter controlled by using SVPWM has better output voltage efficiency when compared with Variable Speed Drive (VSD) inverters that sold in the market. The test data methode using osiloscope, voltmeter and also current clamp proved the result that SVPWM inverter controlled has an voltage efficiency $83.3 \%$ at a frequency of $50 \mathrm{~Hz}$. It is better if compared Variable Speed Drive by using Volt / Hertz control methods that has output voltage efficiency 75,9\% at a frequency $50 \mathrm{~Hz}$. In testing the $2.2 \mathrm{KW} 3$ phase induction motor, it is proved that SVPWM Inverter method capable to suppressing the starting current $59.1 \%$ initially and reduce the consumption of the nominal current 90.1 $\%$ at a frequency $50 \mathrm{~Hz}$.
\end{abstract}

Keywords: variable speed drive, three-phase inverter, space vector pulse width modulation, three-phase induction motor.

\section{PENDAHULUAN}

Dengan berkembangnya ilmu mekatronika, pengendalian motor induksi dengan cara mengubah tegangan dan frekuensi sumber secara berimbang dan bersamaan dapat diimplementasikan. Alat seperti ini umumnya dinamakan Variable Speed Drive (VSD) inverter yang terkendali frekuensi dan amplitudonya. Inverter dapat dikendalikan dengan beberapa metode yaitu Sinusoidal Pulse Width Modulation (PWM), scalar control, dan yang saat ini diteliti yaitu dengan metode Space Vector Pulse Width Modulation (SVPWM).

Metode pengendalian SPWM merupakan modulasi sinyal yang membandingkan sinyal referensi biasanya berupa gelombang sinusoida frekuensi rendah dengan sinyal carrier biasanya gelombang segitiga pada frekuensi tinggi dalam suatu perbandingan amplitudo yang disebut dengan indeks modulasi [1]. Indeks modulasi dinyatakan dengan: 
$M=A r / A c$

dengan

$\begin{array}{ll}M & = \\ A r & = \\ A c & =\end{array}$

Indeks modulasi

$=\quad$ Amplitudo maksimum segitiga

Prinsip kerja pembangkitan sinyal SPWM adalah pengaturan gelombang sinusoida untuk menghasilkan lebar pulsa, hal ini ditunjukkan pada gambar 1:
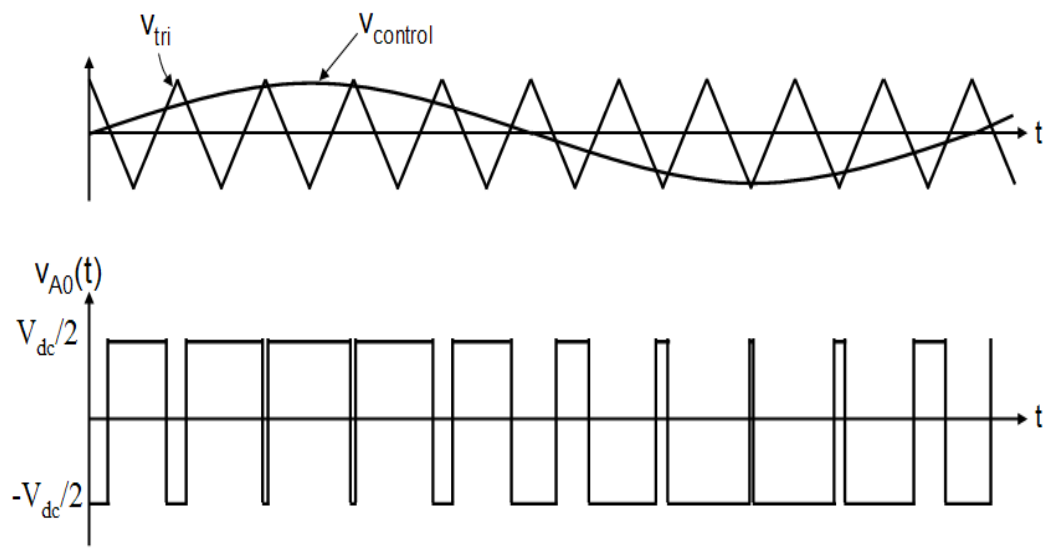

Gambar 1. Teknik Modulasi Lebar Pulsa [2]

Pada gambar 1 menunjukkan modulasi sinyal referensi berupa gelombang sinus dengan sinyal carrier berupa gelombang segitiga. Modulasi kedua gelombang tersebut menghasilkan pulsa pengendali saklar daya inverter. Jika metode SPWM ini diaplikasikan sebagai pengendali inverter maka pulsa keluaran inverter bernilai $1 / 2$ VDC pada saat gelombang referensi lebih positif dari gelombang segitiga dan bernilai $-1 / 2$ VDC ketika gelombang sinus lebih negatif dari gelombang segitiga [3]. Dengan melihat realita bahwa tegangan keluaran inverter hanya bernilai $1 / 2$ VDC maka dikembangkan metode baru yaitu SVPWM yang bertujuan meningkatkan tegangan keluaran inverter.

Pada pengendalian motor induksi 3 fasa, metode pengendalian SPWM inverter memperlakukan masing-masing sinyal referensi 3 fasa sebagai identitas yang terpisah satu dengan yang lainya hal ini menyebabkan jangkauan tegangan keluaran inverter tidak bisa maksimal sebab indeks modulasi terbatasi oleh gelombang pada masing-masing fasa. Metode SVPWM mengambil semua sinyal referensi 3 fasa secara simultan kedalam kerangka acuan 2 fasa dalam bentuk kompleks [4-5]. Representasi tegangan 3 fasa tersebut membentuk vektor tegangan referensi yang berada disepanjang 1 periode gelombang referensi atau $360^{\circ}$ listrik hal ini menyebabkan metode SVPWM menghasilkan tegangan keluaran lebih tinggi dibandingkan dengan metode SPWM. Perbedaan jangkauan indeks modulasi terhadap tegangan keluaran inverter 3 fasa dengan metode SPWM dan SVPWM ditunjukkan pada gambar 2:

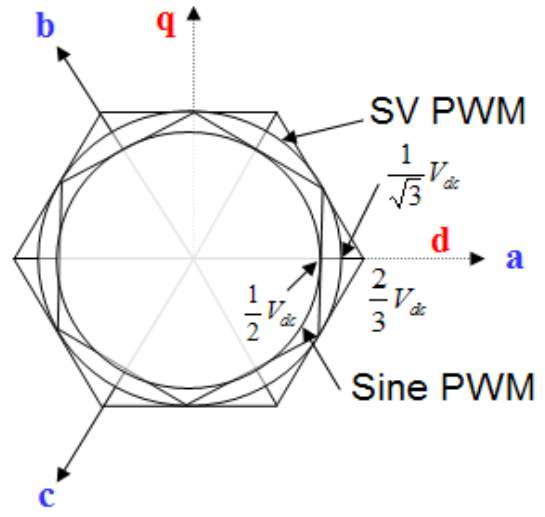

Gambar 2. Perbandingan Tegangan SPWM Dan SVPWM [4]

Gambar 2 menunjukkan locus tegangan yang dihasilkan oleh inverter 3 fasa yang menggunakan metode pengendalian SPWM dan metode pengendalian SVPWM. Dijelaskan bahwa dengan menggunakan metode SPWM tegangan keluaran maksimal yang dihasilkan adalah $1 / 2$ VDC sedangkan dengan metode SVPWM tegangan DC dapat dimaksimalkan hingga $1 / \sqrt{3} \mathrm{~V} \mathrm{DC}$ atau meningkat $15 \%$. 


\section{METODOLOGI PENELITIAN}

Prinsip pengendalian motor Induski 3 fasa dengan metode SVPWM adalah memperlakukan motor induksi sebagaimana pada motor DC. Pada motor DC, fluksi stator $\psi_{s}$ dihasilkan oleh arus yang dialirkan pada belitan medan stator (field winding) dan fluksi rotor $\psi_{r}$ dihasilkan oleh arus yang dialirkan ke belitan jangkar (armature winding) melalui sikat dan komutator. Dengan sistem ini selalu menyebabkan posisi medan magnet stator dan arus pada belitan jangkar saling tegak lurus sehingga torsi elektromagnet yang dihasilkan kedua medan magnet tersebut selalu maksimum [5].

Untuk mengendalikan motor induksi seperti mengendalikan motor DC maka diperlukan pemodelan secara matematis untuk merepresentasikan variabel tegangan, arus, dan fluksi motor induksi. Variabel tersebut dapat direpresentasikan dalam bentuk vektor ruang (space vector) dengan menggunakan sebuah kerangka acuan yang didasarkan pada transformasi elemen tiga fasa menjadi elemen dua fasa. Untuk menyelesaikan pemodelan matematis motor induksi dilakukan dalam 2 kerangka acuan yaitu kerangka acuan stator atau acuan diam dan kerangka acuan rotor atau acuan bergerak. Dalam notasi matematika kerangka acuan diam dinotasikan dalam sumbu $\alpha, \beta$ sedangkan kerangka acuan bergerak dinyatakan dengan notasi d,q. Penurunan persamaan arus stator dan rotor dengan menggunakan metode kendali vektor ruang dapat memisahkan antara arus penghasil fluks rotor dan arus penghasil torsi elektromagnetik [6]. Transformasi arus tiga fasa $\left(I_{a}, I_{b}, I_{c}\right)$ menjadi dua fasa kerangka acuan diam $\left(I_{\alpha}, I_{\beta}\right)$ yang saling tegak lurus satu sama lain dinyatakan dengan menggunakan transformasi Clarke dalam bentuk persamaan berikut:

$\left[\begin{array}{l}i_{\alpha} \\ i_{\beta}\end{array}\right]=\frac{2}{3}\left[\begin{array}{rrr}1 & -\frac{1}{2} & -\frac{1}{2} \\ 0 & \frac{\sqrt{3}}{2} & -\frac{\sqrt{3}}{2}\end{array}\right]\left[\begin{array}{l}i_{a} \\ i_{b} \\ i_{c}\end{array}\right]$

Persamaan 2 juga berlaku untuk persamaan tegangan.

$i_{a}, \quad i_{b}, \quad i_{c}$ adalah arus dari masing-masing fasa pada bagian stator mesin induksi, maka dapat didefinisikan bahwa: is $=i a+\alpha i b+\alpha^{2} i c$ dimana $\alpha=e^{j \frac{2}{3} \pi}$ dan $\alpha^{2}=e^{j \frac{4}{3} \pi}$

Jika $\left(i_{a}, i_{b}, i_{c}\right)$ adalah arus pada sistem tiga fasa maka untuk mendapatkan arus stator dari kerangka acuan tiga koordinat ( $a, b, c)$ ditunjukkan pada gambar 3:

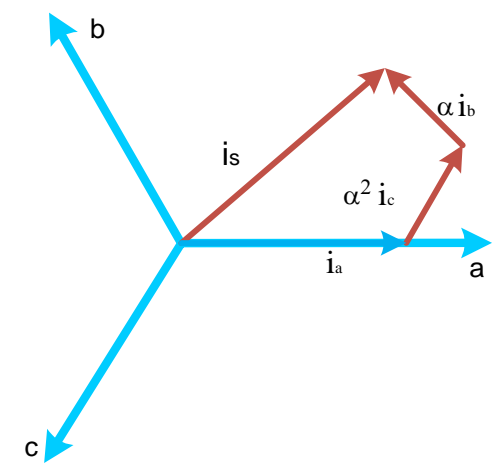

Gambar 3. Arus Stator Pada Koordinat (a,b,c) [7]

Gambar 3 menunjukkan sumber 3 fasa $(a, b, c)$ yang menjelaskan arus stator dalam bentuk sinusoida tergeser $120^{\circ}$ listrik. Sistem ini menghasilkan vektor arus stator yang merupakan penjumlahan kompleks dari fasa $(\mathrm{a}, \mathrm{b}, \mathrm{c})$. Kemudian dari sistem tiga koordinat ditransformasikan menjadi sistem time invariant dua koordinat. Perubahan sistem tiga fasa menjadi sistem time invariant dua koordinat dapat dipisahkan menjadi dua langkah yaitu:

$\begin{array}{lll}\text { Transfomasi Clarke } & (\mathrm{a}, \mathrm{b}, \mathrm{c}) \rightarrow & (\alpha, \beta) \\ \text { Transfomasi Park } & (\alpha, \beta) \rightarrow & (d, q)\end{array}$

Dengan transformasi Clarke, sistem 3 fasa $(a, b, c)$ dapat dipresentasikan dalam dua koordinat sumbu tegak lurus $(\alpha, \beta)$ [7]. Dengan asumsi bahwa sumbu a dan sumbu $\alpha$ mempunyai arah vektor yang sama maka kedua sumbu tersebut digambarkan seperti terlihat pada gambar 4. 


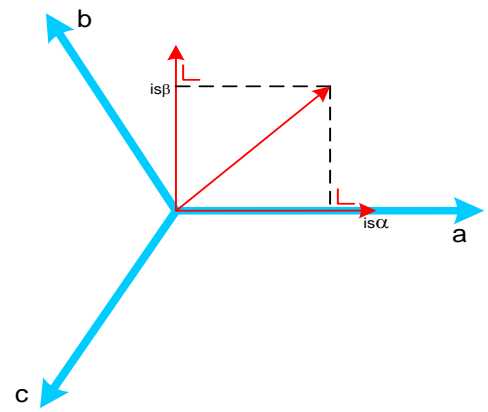

Gambar 4. Transfomasi Clarke $(a, b, c) \rightarrow(\alpha, \beta)[7]$

Gambar 4 menunjukkan transformasi dari sistem 3 fasa menjadi 2 fasa yang saling tegak lurus dengan kerangka acuan diam dalam sumbu $\alpha, \beta$. Dalam hal ini $i_{s \alpha}$ selalu sefasa dengan $i_{a}$ sedangkan $i_{s} \beta$ tegak lurus terhadap $i_{s \alpha}$ dengan nilai: $i_{a \beta}=\frac{1}{\sqrt{a}} i_{a}+\frac{2}{\sqrt{a}} i_{b}$.

Sedangkan untuk mempresentasikan kerangka acuan tetap $(\alpha, \beta)$ menjadi kerangka acuan bergerak $(d, q)$, maka digunakan transformasi Park. Transformasi Park dapat dilihat pada gambar 5:

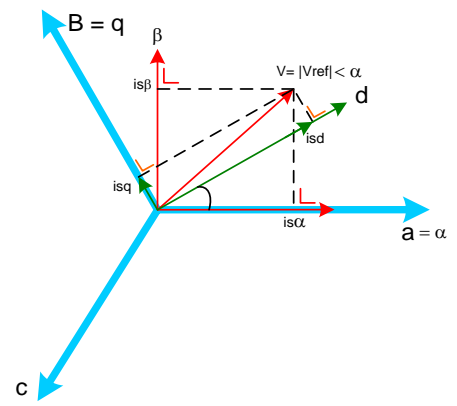

Gambar 5. Transfomasi Park $(\alpha, \beta) \rightarrow(d, q)[7]$

Gambar 5 menunjukkan proyeksi sistem dua dimensi tegak lurus $(\alpha, \beta)$ menjadi sistem dua dimensi bergerak $(d, q)$. Proyeksi sistem ini menghasilkan arus direct $\left(\mathrm{i}_{\mathrm{d}}\right)$ yang merepresentasikan fluksi dan arus quadratur $\left(\mathrm{i}_{\mathrm{q}}\right)$ yang merepresentasikan torsi. Besarnya komponen fluksi dan torsi dalam sistem ini dijelaskan dengan persamaan sebagai berikut:

$$
\left[\begin{array}{l}
i_{d} \\
i_{q}
\end{array}\right]=\left[\begin{array}{cc}
\cos \left(\omega_{e} t\right) & -\sin \left(\omega_{e} t\right) \\
\sin \left(\omega_{e} t\right) & \cos \left(\omega_{e} t\right)
\end{array}\right]\left[\begin{array}{l}
i \alpha \\
i \beta
\end{array}\right]
$$

Sedangkan $\mid$ Iref $\mid=\sqrt{I_{d}^{2}+I_{q}^{2}}$ dan $\alpha=\tan ^{-1} \frac{I_{q}}{I_{d}}$

Persamaan 3 juga berlaku pada persamaan tegangan. Dengan memproyeksikan menjadi sistem 2 fasa (d,q) yang mengendalikan fluksi dan torsi secara terpisah maka motor induksi dapat dikendalian kedalam state space vector atau time domain sehingga sistem pengendalian menjadi lebih mudah untuk dikerjakan secara digital.

\section{IMPLEMENTASI SVPWM PADA INVERTER 3 FASA}

Inverter 3 fasa terdiri dari 6 buah saklar elektronik, kombinasi 6 saklar elektronik tersebut menyebabkan munculnya tegangan AC 3 fasa pada sisi beban inverter. Setiap fasa dihasilkan dari sepasang saklar elektronik yang dinyalakan secara berlawanan (jika saklar bagian atas on maka saklar bagian bawah akan off dan sebaliknya).

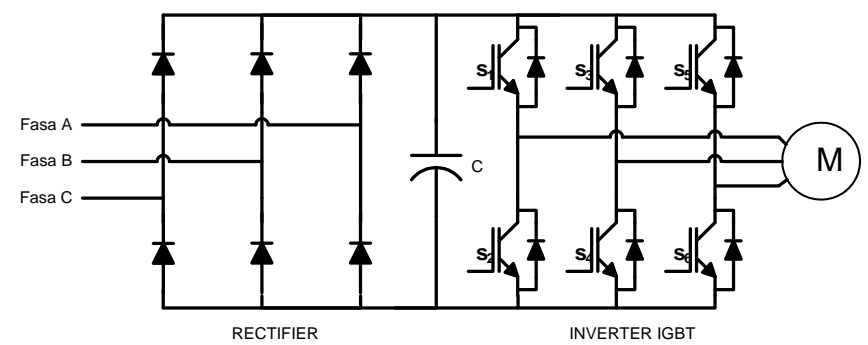

Gambar 6. Inverter 3 Fasa Dengan Saklar IGBT [8] 
Dengan teknik kendali SVPWM maka konfigurasi 6 buah saklar daya inverter menghasilkan 8 kemungkinan penyaklaran seperti pada gambar 7:
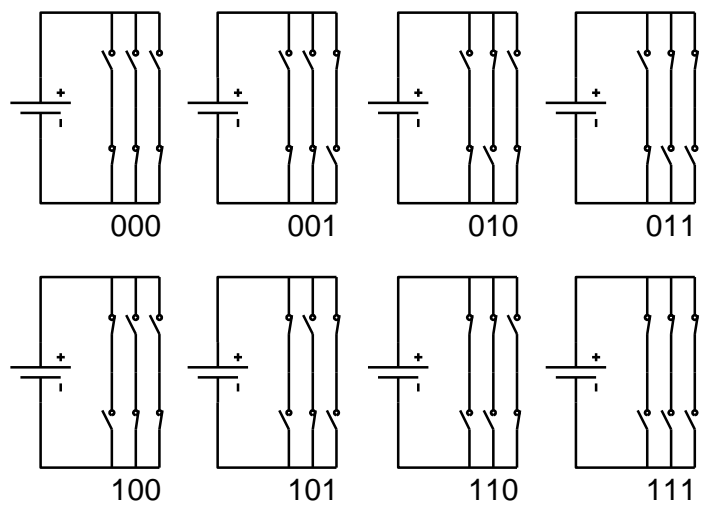

Gambar 7. Konfigurasi Saklar Daya Inverter 3 Fasa 3 Lengan [9]

Gambar 7 menjelaskan pola penyaklaran inverter yang dibentuk dari 3 pasang saklar daya yang dapat dibentuk dengan teknik SVPWM sehingga menghasilkan 8 kondisi penyaklaran inverter. Dalam sistem kendali SVPWM tegangan fasa-fasa dan fasa-netral dihasilkan oleh delapan konfigurasi switching yang terdiri dari enam buah vektor tegangan aktif (active voltage vectors) yang saling tergeser 60 derajat dan dua buah vektor tegangan nol (zero voltage vectors) yang berada di pusat koordinat. Suatu vektor tegangan yang berada pada sumbu $\alpha \beta$ selalu merepresentasikan tiga buah tegangan line to line pada keluaran PWM converter dengan arah perputaran berlawanan dengan arah jarum jam. Pembagian vektor gelombang sinusoida 3 fasa sepanjang $360^{\circ}$ menjadi 6 buah sektor ditunjukkan pada gambar 8:

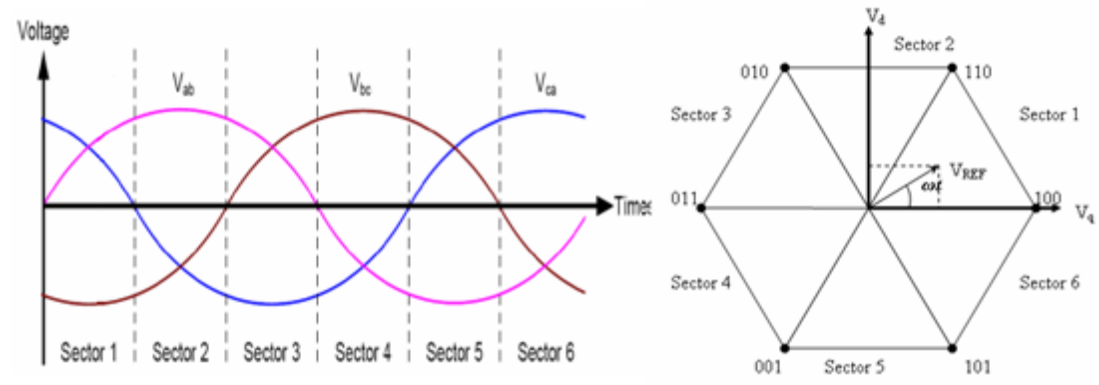

Gambar 8. Gelombang Sinusoida 3 Fasa, Ruang Vektor3 Fasa [10]

Gambar 8 menunjukkan vektor tegangan dalam domain waktu dan pada sumbu $\alpha \beta$ dalam bentuk hexagonal. SVPWM ditujukan untuk membentuk tegangan keluaran PWM converter mendekati tegangan referensinya dengan 8 konfigurasi penyaklaran sehingga harus membagi domain waktu $360^{0}$ menjadi 6 buah sektor sebesar $60^{\circ}$. Masing-masing sektor menghasilkan 3 buah pola penyaklaran yang berhubungan dengan setiap pasang saklar daya inverter 3 fasa. Pola penyaklaran pada setiap sektor dapat dibuat dalam suatu pengkondisian seperti pada tabel 1 .

Tabel 1. Pola penyaklaran vektor pada tiap sektor

\begin{tabular}{ccccccccc}
\hline Urutan fasa & V0 & V1 & V2 & V3 & V4 & V5 & V6 & V7 \\
\hline U & 0 & 1 & 1 & 0 & 0 & 0 & 1 & 1 \\
V & 0 & 0 & 1 & 1 & 1 & 0 & 0 & 1 \\
W & 0 & 0 & 0 & 0 & 1 & 1 & 1 & 1 \\
\hline
\end{tabular}

Tabel 1 menyatakan pola penyaklaran vektor pada setiap sektor, berdasar tabel tersebut dapat dibuat suatu pendekatan untuk membentuk tegangan referensi dalam setiap sektor. Sebagai contoh suatu vektor tegangan referensi $\boldsymbol{V}_{\boldsymbol{s} \boldsymbol{1}}$ berada pada sektor-1 sehingga berada diantara vektor tegangan aktif $\boldsymbol{V}_{\boldsymbol{1}}$ dan $\boldsymbol{V}_{\boldsymbol{2}}$ [10]. Persamaan yang dapat diturunkan dari kondisi tersebut adalah:

$$
\begin{aligned}
& \boldsymbol{V} T_{s}=V_{1} t_{1}+V_{2} t_{2} \\
& T_{s}=\text { waktu sampling } \\
& t_{1}=\text { durasi waktu } P W M \text { converter membentuk vektor } V_{1} \\
& t_{2}=\text { durasi waktu } P W M \text { converter membentuk vektor } V_{2}
\end{aligned}
$$


Karena $T_{s}=\left(t_{0}+t_{1}+t_{2}\right)$ maka dibutuhkan waktu tambahan sebesar $t_{0}$ di setiap sektor. Agar nilai persamaan (5) tetap berlaku maka $t_{0}$ harus dikalikan dengan vektor tegangan nol (dapat merupakan $\boldsymbol{V}_{\boldsymbol{0}}$ atau $\boldsymbol{V}_{7}$ ).sehingga persamaan tersebut menjadi:

$$
\mathrm{V}_{\mathrm{s} 1} T_{s}=t_{0}\left(\mathrm{~V}_{0} / \mathrm{V}_{7}\right)+\mathrm{V}_{1} t_{1}+\mathrm{V}_{2} t_{2}
$$

atau

$$
\mathrm{V}_{\mathrm{s} 1}=\frac{t_{0}}{T_{s}}\left(\mathrm{~V}_{0} / \mathrm{V}_{7}\right)+\frac{t_{1}}{T_{s}} \mathrm{~V}_{1}+\frac{t_{2}}{T_{s}} \mathrm{~V}_{2}=d_{0}\left(\mathrm{~V}_{0} / \mathrm{V}_{7}\right)+d_{1} \mathrm{~V}_{1}+d_{2} \mathrm{~V}_{2}
$$

Dimana $\mathrm{V}_{\mathrm{s} 1}$ merupakan tegangan refrensi pada sektor 1. Pembentukan tegangan referensi pada setiap vektor ditunjukkan seperti pada gambar 9.

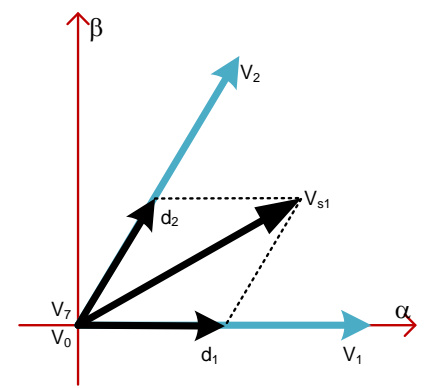

\section{Gambar 9. Tegangan Referensi Dibentuk Oleh 4 Vektor [10]}

Dari gambar 9, $\mathrm{V}_{\mathrm{s} 1}$ merupakan nilai tegangan referensi yang dihasilkan dari resultan magnitude vektor $\mathrm{V}_{1}$ yang disimbolkan $\mathrm{d}_{1}$ dengan magnitude vektor 2 yang disimbolkan dengan $\mathrm{d}_{2}$. Tegangan $\mathrm{V}_{\mathrm{s} 1}$ yang bekerja pada sektor 1 dibentuk dari 4 buah vektor $V_{0}, V_{1}, V_{2}$ dan $V_{7}$ yang memiliki logika penyaklaran yang ditunjukkan pada tabel 2

Tabel 2. Logika penyaklaran vektor tegangan pada sektor 1

\begin{tabular}{ccccc}
\hline Urutan fasa & $\boldsymbol{V 0}$ & $\boldsymbol{V 1}$ & $\boldsymbol{V 2}$ & $\boldsymbol{V 7}$ \\
\hline U & 0 & 1 & 1 & 1 \\
V & 0 & 0 & 1 & 1 \\
W & 0 & 0 & 0 & 1 \\
\hline
\end{tabular}

Tegangan disepanjang sektor 1 dibentuk oleh 4 buah vektor V0, V1, V2 dan V7. V0 merupakan vektor dipusat koordinat yang bernilai 000, V1 adalah vektor 1 benilai 100, V2 adalah vektor 2 dengan nilai 110 dan V7 adalah vektor dipusat koordinat yang bernilai 111. Dengan menggunakan pola seperti pada tabel 2 dapat digambarkan pola penyaklaran pada sektor 1 hinga sektor 6 seperti ditunjukkan pada gambar 10
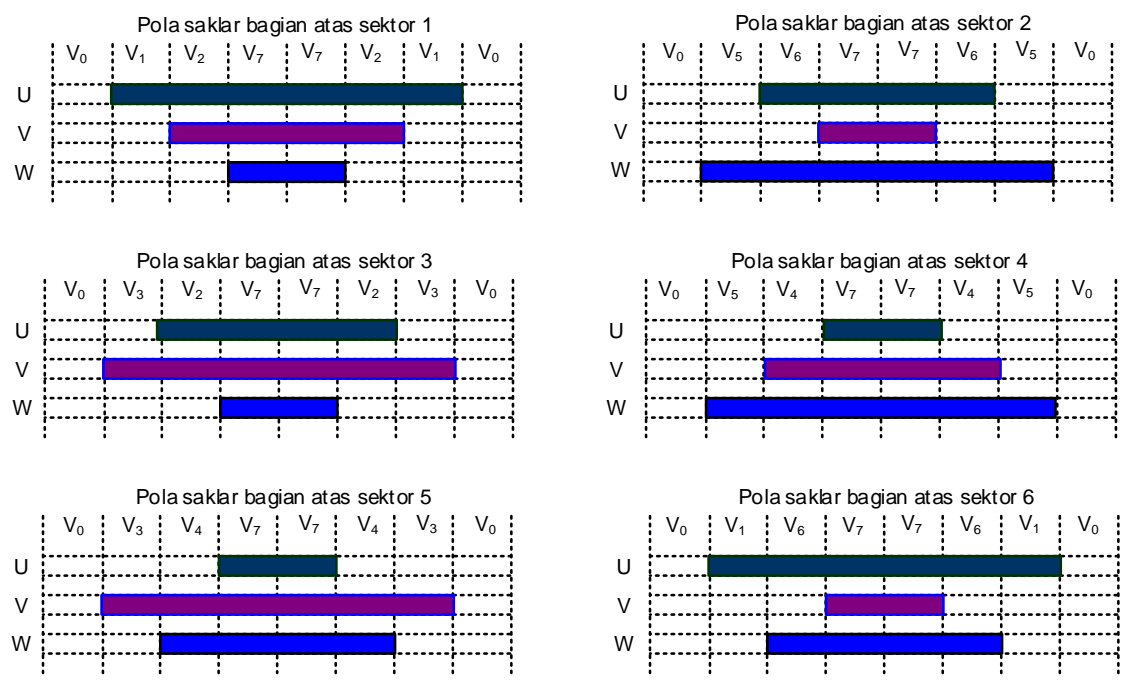

Gambar 10. Pola Penyaklaran SVPWM Pada Semua Sektor [10] 


\section{HASIL- HASIL PENGUJIAN}

Pengujian alat dilakukan dengan membandingkan tegangan keluaran inverter yang menggunakan teknik pengendalian SVPWM dengan VSD inverter yang dikendalikan menggunakan teknik Volt/Hertz. Data-data pengukuran yang diambil meliputi pengukuran frekuensi berdasarkan pembacaan osiloskop tegangan keluaran inverter dan respon kecepatan yang dihasilkan dari pengukuran kecepatan motor induksi 3 fasa. Tabel 3 dan tabel 4 menunjukkan data pengukuran yang dihasilkan dari inverter yang menggunakan teknik pengendalian SVPWM dan inverter yang menggunakan teknik pengendalian Volt/hertz.

Tabel 3. Data pengujian inverter SVPWM

\begin{tabular}{cccccccc}
\hline $\begin{array}{c}\text { Tegangan } \\
\text { Referensi } \\
(\text { volt })\end{array}$ & $\begin{array}{c}\text { Frekuensi } \\
(\text { Hertz })\end{array}$ & $\begin{array}{c}N_{h} \\
(\boldsymbol{R P M})\end{array}$ & $\begin{array}{c}N_{u} \\
(\boldsymbol{R P M})\end{array}$ & Slip & $\begin{array}{c}\boldsymbol{V}_{\boldsymbol{F}-\boldsymbol{F}} \\
(\text { Volt })\end{array}$ & $\begin{array}{c}\boldsymbol{V}_{\boldsymbol{F}-\boldsymbol{N}} \\
(\text { Volt })\end{array}$ & $\begin{array}{c}\text { Effisiensi } \\
\text { Tegangan }\end{array}$ \\
\hline 0.49 & 2 & 60 & 0 & 1.000 & 8 & 4 & 0,04 \\
1.00 & 6 & 180 & 70 & 0.611 & 24 & 14 & 0,11 \\
1.49 & 10 & 300 & 240 & 0.200 & 46 & 26 & 0,21 \\
2.06 & 12 & 360 & 349 & 0.031 & 57 & 32 & 0,26 \\
2.50 & 14 & 420 & 464 & 0.105 & 69 & 37 & 0,31 \\
3.00 & 16 & 480 & 573 & 0.194 & 76 & 42 & 0,35 \\
3.57 & 19 & 570 & 652 & 0.144 & $\mathbf{8 7}$ & $\mathbf{4 8}$ & 0,40 \\
4.01 & 22 & 660 & 699 & 0.059 & 98 & 54 & 0,45 \\
4.50 & 24 & 720 & 739 & 0.026 & 107 & 59 & 0,49 \\
5.06 & 27 & 810 & 803 & 0.009 & 116 & 64 & 0,53 \\
5.51 & 30 & 900 & 945 & 0.050 & 124 & 69 & 0,56 \\
6.07 & 33 & 990 & 1065 & 0.076 & 133 & 74 & 0,60 \\
6.49 & 35 & 1050 & 1109 & 0.056 & 142 & 79 & 0,65 \\
7.08 & 38 & 1140 & 1194 & 0.047 & 151 & 85 & 0,69 \\
7.50 & 41 & 1230 & 1219 & 0.009 & 159 & 88 & 0,72 \\
8.00 & 44 & 1320 & 1382 & 0.047 & 167 & 93 & 0,76 \\
8.50 & 47 & 1410 & 1451 & 0.029 & 175 & 97 & 0,80 \\
9.06 & 51 & 1500 & 1534 & 0.023 & 183 & 101 & 0,83 \\
\hline
\end{tabular}

Tabel 4. Data pengujian VSD (Inverter Volt/Hertz)

\begin{tabular}{ccccccc}
\hline $\begin{array}{c}\text { Frekuensi } \\
(\boldsymbol{H z})\end{array}$ & $\begin{array}{c}\boldsymbol{N}_{\boldsymbol{h}} \\
(\boldsymbol{R P M})\end{array}$ & $\begin{array}{c}\boldsymbol{N}_{\boldsymbol{u}} \\
(\boldsymbol{R P M})\end{array}$ & Slip & $\begin{array}{c}\boldsymbol{V}_{\boldsymbol{F - F}} \\
(\text { Volt })\end{array}$ & $\begin{array}{c}\boldsymbol{V}_{\boldsymbol{F}-\boldsymbol{N}} \\
(\text { Volt })\end{array}$ & $\begin{array}{c}\text { Effisiensi } \\
\text { Tegangan }\end{array}$ \\
\hline 0 & 0 & 0 & 0.000 & & & \\
5 & 150 & 36 & 0.760 & 17 & 9 & 0.077 \\
10 & 300 & 355 & 0.183 & 42 & 24 & 0.191 \\
15 & 450 & 372 & 0.173 & 69 & 38.66 & 0.314 \\
20 & 600 & 385 & 0.358 & 91 & 52 & 0.414 \\
25 & 750 & 625 & 0.167 & 105 & 60.7 & 0.477 \\
30 & 900 & 997 & 0.108 & 121.5 & 69.4 & 0.552 \\
35 & 1050 & 1045 & 0.005 & 137 & 78.8 & 0.623 \\
40 & 1200 & 1231 & 0.026 & 155 & 87.2 & 0.705 \\
45 & 1350 & 1437 & 0.064 & 165 & 93.6 & 0.750 \\
50 & 1500 & 1524 & 0.016 & 167 & 95.9 & 0.759 \\
\hline
\end{tabular}

Selain Pengujian dengan membandingkan inverter SVPWM yang dibuat dengan VSD inverter, alat ini juga dibandingkan dengan rangkaian DOL untuk membandingkan arus mula dan arus nominal pada motor induksi 1 KVA. Data pengujian yang dihasilkan ditunjukkan pada tabel 5. 
Tabel 5. Perbandingan arus motor DOL dan terkendali SVPWM

\begin{tabular}{ccccc}
\hline \multirow{2}{*}{$\boldsymbol{F A S A}$} & \multicolumn{2}{c}{$\boldsymbol{I s}$} & \multicolumn{2}{c}{ In } \\
& SVPWM & DOL & SVPWM & DOL \\
\hline $\mathrm{A}$ & 1,12 & 2,74 & 0,11 & 1,11 \\
$\mathrm{~B}$ & 1,15 & 2,80 & 0,14 & 1,19 \\
$\mathrm{C}$ & 1,10 & 2,76 & 0,13 & 1,16 \\
\hline
\end{tabular}

Pengujian Arus Mula pada inverter SVPWM diukur pada saat motor dalam kondisi stalling dan pengukuran arus nominal dilakukan pada saat frekuensi keluaran inverter SVPWM 50 Hz. Dari Tabel 4.8 membuktikan untuk pengendalian motor induksi metode SVPWM mampu menekan lonjakan arus mula (Is) motor hingga sebesar 59,1\% pada saat start dan menekan konsumsi arus pada saat running (In) pada frekuensi $50 \mathrm{~Hz}$ sebesar 90,1\%.

\section{KESIMPULAN}

1) Dari pengujian di laboratorium membuktikan inverter terkendali SVPWM memiliki efisiensi tegangan keluaran pada frekuensi $50 \mathrm{~Hz}$ sebesar 82,7 \%, hal ini lebih baik jika dibandingkan dengan metode Volt/Hertz yang menghasilkan efisiensi tegangan keluaran pada frekuensi 50 $\mathrm{Hz}$ sebesar 75,9 \%. Sedangkan pada frekuensi dibawah $50 \mathrm{~Hz}$, metode SVPWM selalu menghasilkan effisiensi tegangan jauh lebih baik dibandingkan dengan metode Volt/Hertz.

2) Setelah melakukan pengujian inverter terkendali SVPWM dengan rangkaian direct on line (DOL) terbukti metode SVPWM inverter mampu menekan lonjakan arus mula dan juga arus yang dikonsumsi oleh beban motor pada saat running. Dari pengujian dengan metode DOL, sistem SVPWM mampu menekan arus mula sebesar 59,1\% dan menekan konsumsi arus nominal pada frekuensi $50 \mathrm{~Hz}$ sebesar $90,1 \%$.

3) Dengan menekan konsumsi arus pada saat start dan pada saat running maka akan berdampak pada penghematan biaya operasional motor tersebut.

\section{DAFTAR PUSTAKA}

[1] Nguyen Phung Quang., Jörg-Andreas Dittrich, "Vector Control of Three Phase AC Machine”, eISBN: 978-3-540-79029-7, September 1965.

[2] Rashid, Muhammad H, "Power Electronics: Circuit, Devices, And Aplications", Prentice Hall Inc, London, 1988.

[3] Riyadi, Slamet, "Penggerak Kecepatan Variable Pada Motor Induksi Tiga Fasa Berbasis V/Hz dan Direct Torque Control “, Unika Soegijapranata, 2010.

[4] Keyhani, Ali., Woo jung .J, "Space vector PWM Inverter", Mechatronic systems laboratory, the Ohio State University, February 2005.

[5] Soemarto, "Metode Baru Dalam Identifikasi Parameter Motor Induksi", Epsilon : Journal of Electrical Engineering and Information Technology Vol. 1, No. 1, July 2003.

[6] Ojo, O., Consoli, A., dan Lipo, T.A., 1990, "An Improved Model of Saturated Induction Machines", IEEE Trans. on Industry Applications, vol 26 no 2, maret, 1990.

[7] "Field Orientated Control of 3-Phase AC-Motors", Literature Number: BPRA073, Texas Instruments Europe, February 1998.

[8] Musafa. A, "Simulasi Perancangan Pengendali Vektor Arus Pada Motor Induksi 3 Fasa dengan CMEX S-FUNCTION”, Seminar, Universitas Indonesia, 2007.

[9] [9] Bose, Bimal K, Modern Power Electronics and AC Drives, The University of Tennessee, Knoxville, Prentice Hall, Inc. United State of America, 2002.

[10] Kelvin Lye kwong Loong., Nik ramzi bin Idris, Microcontroller Based Space Vector Modulation (SVM) Signal Generator, Faculty of Electrical Engineering UTM, May 2008. 